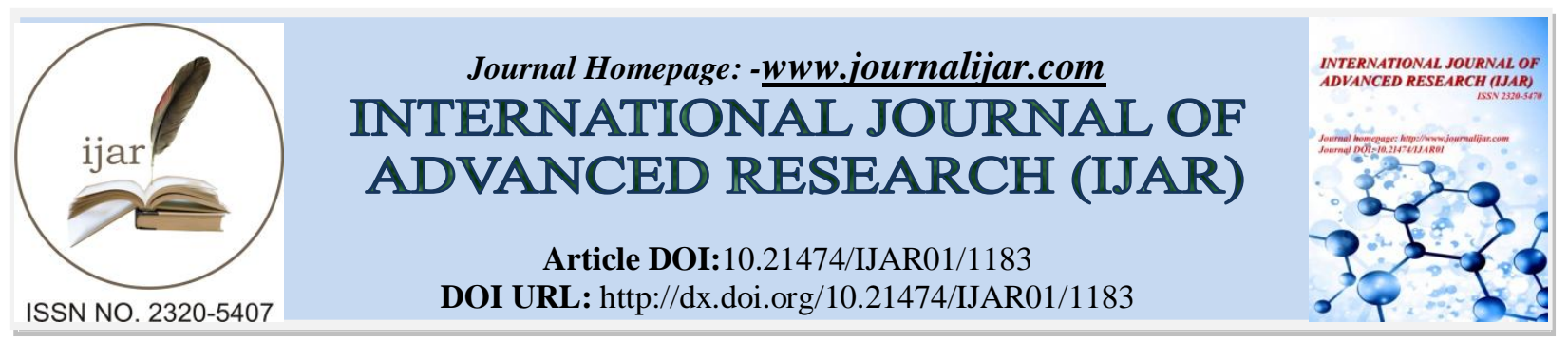

RESEARCH ARTICLE

\title{
EFFECTS OF ABATTOIR EFFLUENT ON THE PHYSICOCHEMICAL PROPERTIES OF SURROUNDING SOILS IN CALABAR METROPOLIS.
}

\author{
V. F Ediene, O. B. Iren and M. M. Idiong.
}

Department of Soil Science, Faculty of Agriculture, University of Calabar.

\section{Manuscript Info}

Manuscript History

Received: 19 June 2016

Final Accepted: 23 July 2016

Published: August 2016

Key words:-

Abattoir, Effluent, Physicochemical, Soil.

\begin{abstract}
This study was conducted to assess the levels of $\mathrm{pH}$, organic carbon, total nitrogen $(\mathrm{N})$, available phosphorus, and exchangeable $\mathrm{Ca}, \mathrm{Mg}, \mathrm{K}$ and $\mathrm{Na}$ in soils surrounding Atimbo, IkotEneobong and Nasarawa abattoirs. Results of the physicochemical analyses showed that the soils were loamy sand in texture, with $\mathrm{pH}$ range of 4.9-5.2 and 6.1-7.2 for the control and abattoir effluent contaminated soils, respectively. Abattoir effluent contaminated soils had higher values for organic carbon (6.1-7.6 \%), total nitrogen (0.18-0.65 \%) and available phosphorus (12.25-37.75 mgkg-1) than the control site. The results also indicate increased levels of calcium, magnesium, potassium and sodium in the abattoir effluent contaminated soils across the three locations. Indiscriminate discharge of abattoir effluent into surrounding soils should therefore be checked to avoid a buildup of nutrients which may encourage luxury consumption in crops grown within the vicinity.
\end{abstract}

Copy Right, IJAR, 2016,. All rights reserved.

\section{Introduction:-}

With the recent upsurge in the population of people in Calabar, owing to its status as a tourism destination, there has been an increase in demand for meat, to meet the protein demand of the populace. This has resulted in the increasing number and indiscriminate siting of abattoirs in Calabar. There are growing concerns over the increasing and indiscriminate discharge of abattoir effluent into the environment.

Abattoir effluent is complex in composition and may exert an effect on the environment. Abattoir waste comprises of organic and inorganic solids, blood, fat, long hair, faeces, undigested feed materials, large fragments of plants, worn out cells, intestinal lining, mucus, water, chemicals mostly cellulose-fibre, calcium, magnesium, iron, phosphorus, sodium, ash and microorganismsetc. (Ubwa, et al., 2013,Ezeoha and Ugwuishiwu, 2011). Waste effluent could alter the physicochemical properties of the soil (Edward, 1990). The indiscriminate discharge of waste waterinto the soil could cause certain elements (example, phosphorus and calcium etc.) previously absent or present in minute quantities to be introduced leading to the increase in the content of these chemical elements and thus altering the physicochemical nature of the soil (Tortoraet al., 2007).Continuous discharge of abattoir effluent into the soil could fix or complex plant nutrients thereby making them unavailable for plant use thus affecting the fertility of the soil which may lead to low productivity in the surrounding farmlands (Rabahet al., 2010).

Corresponding Author:-V. F Ediene

Address:-Department of Soil Science, Faculty of Agriculture, University of Calabar 
Soil health is a very important factor in Calabar metropolis, where most of the soils are infertile, with low nutrient content, probably due to the high intensity of rainfall and coastal plain sands that overly the soils. The increasing number of abattoir in Calabar is of great concern. There is thereforetheneed to assess the physicochemical properties of soils surrounding abattoirs in Calabar Metropolis, where effluents are discharged into without environmental management practices, with the aim of ascertaining their present status and proffering better management techniques.

\section{Materials and Methods:-}

The soil samples used in this study were collected from Atimbo, IkotEneobong and Nasarawa abattoirs and environs. Three sampling points were mapped out around each abattoir location. The reference point (1) was at the point of discharge of the effluent from the abattoir into the soil. Point (2) was at a distance of $20 \mathrm{~m}$ from the reference point and still within the effluent site. Point 3 was $100 \mathrm{~m}$ from the reference point and served as the control. Composite samples were collected at each sampling point at a depth of $0-30 \mathrm{~cm}$ using soil auger. Nine composite samples were collected in all, three per location.

\section{Laboratory Analysis:-}

Samples obtained from the study location were processed by air-drying at room temperature, crushing and sieving with $2 \mathrm{~mm}$ sieve. Finely sieved soil samples were subjected to physicochemical analyses.

Particle size analysis was carried out by Bouyoucos Hydrometer method (Bouyoucos, 1957). The soil pH was measured using a glass electrode $\mathrm{pH}$ meter. The organic carbon content of the soil was determined by Walkley and Black (1934) wet oxidation method, Total nitrogen $(\mathrm{N})$ by the Kjeldahl digestion method (Black et al., 1965) andavailable phosphorus by the Bray P1 method, using a solution of $1 \mathrm{M} \mathrm{NH}_{4} \mathrm{~F}$ and $0.5 \mathrm{ml} \mathrm{Hcl}$ in distilled water as the extractant, (Bray and Kurtz, 1945).

Exchangeable $\mathrm{Ca}, \mathrm{Mg}, \mathrm{K}$ and $\mathrm{Na}$ were leached from the soil solution into $1 \mathrm{M}$ ammonium acetate. Sodium and $\mathrm{K}$ in the extract were determined with a flame photometer while $\mathrm{Ca}$ and $\mathrm{Mg}$ were determined with Atomic Absorption Spectrophotometer (AAS).Exchangeable acidity $\left\{\right.$ Hydrogen ion $\left(\mathrm{H}^{+}\right)$and aluminum ion $\left.\left(\mathrm{Al}^{3+}\right)\right\}$ was determined by the $1 \mathrm{M}$ potassium chloride $(\mathrm{KCl})$ extraction procedure described by Black et al. (1965). The effective cation exchange capacity (ECEC) values of the soil were computed by summation of exchangeable bases and exchangeable acidity. Base saturation values of the soil were computed by summation of exchangeable bases, divided by the effective cation exchange capacity and multiplied by 100.

\section{Results and Discussion:-}

The particle size analysis and chemical properties of the soils contaminated with abattoir effluent in Atimbo, IkotEneobong and Nasarawa abattoirs and environs are presented in Tables 1 and 2,respectively.

Particle size analysis shows that sand fraction was dominant in the sampled sites. The sand separates were greater than 76 percent. Silt values ranged between 5.0 and 16.0 percent while values for clay were less than 11.3 per cent. The soils across the three sampled sites were loamy sand in texture (Table1).

The $\mathrm{pH}$ values for the control soils in the three locations (Atimbo, IkotEneobong and Nasarawa) were strongly acidic in reaction with values ranging from 4.9 to 5.2 (Table 2). While slightly acidic to slightly alkaline pH values (6.1-7.4), were obtained for soils at the abattoir effluents contaminated sites. The $\mathrm{pH}$ of $6.7-7.4$ recorded for the contaminated site could result from the modification of the soil reaction by the decomposing abattoir effluent. 
Table 1. Particle size of soils contaminated with abattoir effluent in Atimbo, IkotEneobong andNasarawa abattoirs in Calabar metropolis

\begin{tabular}{|c|c|c|c|c|}
\hline Location of samples & $\begin{array}{l}\text { Sand } \\
\mathrm{gdkg}^{-1}\end{array}$ & Silt & & Texture \\
\hline \multicolumn{5}{|l|}{ CONTROL } \\
\hline Atimbo & 84.7 & 7.0 & 17.0 & Loamy sand \\
\hline IkotEneobong & 87.3 & 1.50 & 11.3 & Loamy sand \\
\hline Nasarawa & 83.7 & 1.50 & 11.3 & Loamy sand \\
\hline \multicolumn{5}{|c|}{ ABATTOIR EFFLUENT SOILS } \\
\hline Atimbo 1 & 83.7 & 1.50 & 13.0 & Loamy sand \\
\hline Atimbo 2 & 76.7 & 2.00 & 33.0 & Loamy sand \\
\hline IkotEneobong 1 & 84.7 & 1.40 & 13.0 & Loamy sand \\
\hline IkotEneobong 2 & 82.7 & 1.50 & 23.0 & Loamy sand \\
\hline Nasarawa 1 & 80.7 & 1.60 & 33.0 & Loamy sand \\
\hline Nasarawa 2 & 82.7 & 1.50 & 23.0 & Loamy sand \\
\hline
\end{tabular}

Table 2:- Chemical properties of soils contaminated with abattoir effluent in Atimbo, IkotEneobong and Nasarawa abattoirs in Calabar metropolis.

\begin{tabular}{|c|c|c|c|c|c|c|c|c|c|c|c|c|}
\hline $\begin{array}{l}\text { Location of } \\
\text { samples }\end{array}$ & $\mathrm{pH}$ & $\begin{array}{l}\text { Organic } \\
\text { carbon } \\
(\%)\end{array}$ & $\begin{array}{l}\mathrm{TN} \\
(\%)\end{array}$ & $\begin{array}{l}\text { Avail. } \\
\text { P } \\
(\mathrm{mg} / \mathrm{kg})\end{array}$ & \multicolumn{4}{|c|}{$\longrightarrow$} & \multicolumn{2}{|c|}{$\begin{array}{l}\text { Exchangeable } \\
\text { acidity } \\
\mathrm{H}^{+} \mathrm{Al}^{3+} \\
\mathrm{cmol} / \mathrm{Kg}\end{array}$} & $\begin{array}{l}\text { ECEC } \\
\mathrm{cmol} / \mathrm{kg}\end{array}$ & \multirow[t]{2}{*}{$\begin{array}{l}\text { Base } \\
\text { Sat. } \\
(\%)\end{array}$} \\
\hline CONTROL & & & & & & & & & & & & \\
\hline Atimbo & 5.2 & 1.0 & 0.08 & 10.25 & 5.6 & 2.4 & 0.09 & 0.07 & 0.24 & 1.8 & 10.20 & 80.0 \\
\hline IkotEneobong & 4.9 & 1.1 & 0.09 & 16.87 & 3.0 & 2.2 & 0.07 & 0.05 & 0.48 & 0.02 & 5.82 & 91.4 \\
\hline Nasarawa & 4.9 & 1.0 & 0.09 & 16.87 & 3.0 & 0.6 & 0.07 & 0.06 & 0.48 & 0.52 & 4.73 & 78.8 \\
\hline Mean & 5.0 & 1.0 & 0.08 & 14.66 & 3.86 & 1.73 & $\mathbf{0 . 0 7}$ & 0.06 & 0.4 & 0.78 & 6.91 & 83.4 \\
\hline $\begin{array}{l}\text { ABATTOIR } \\
\text { EFFLUENT } \\
\text { SOILS }\end{array}$ & & & & & & & & & & & & \\
\hline Atimbo 1 & 6.5 & 6.1 & 0.52 & 25.50 & 13.4 & 4.4 & 0.20 & 0.11 & 0.28 & 0.0 & 18.39 & 98.4 \\
\hline Atimbo 2 & 6.1 & 7.6 & 0.65 & 22.25 & 12.6 & 4.4 & 0.18 & 0.10 & 0.20 & 0.0 & 17.48 & 98.8 \\
\hline IkotEneobong 1 & 6.3 & 7.5 & 0.65 & 27.75 & 15.2 & 9.8 & 0.19 & 0.10 & 0.08 & 0.0 & 25.37 & 99.7 \\
\hline IkotEneobong 2 & 7.2 & 6.5 & 0.53 & 29.63 & 15.6 & 6.4 & 0.22 & 0.11 & 0.04 & 0.0 & 22.37 & 99.8 \\
\hline Nasarawa 1 & 7.4 & 6.5 & 0.34 & 26.50 & 13.6 & 2.0 & 0.19 & 0.12 & 0.00 & 0.0 & 15.91 & 100 \\
\hline Nasarawa 2 & 7.2 & 6.1 & 0.18 & 36.25 & 14.0 & 2.2 & 0.10 & 0.12 & 0.16 & 0.0 & 16.58 & 99.0 \\
\hline Mean & 6.7 & 6.7 & 0.47 & 27.98 & 14.0 & 4.8 & 0.18 & 0.11 & 0.12 & $\mathbf{0}$ & 18.9 & 99.2 \\
\hline
\end{tabular}

The organic carbon content of the soils ranged of 1.0-1.1\% and 6.1-7.6\% for the control and the abattoir effluent contaminated sites,respectively. The soils of the control sites are rated low in organic carbon as values obtained were belowthe critical level of 1.5\% givenby Federal Department of Agriculture and Land Resources (1990)and Landon (1991) and 4.5\% (Holland et al., 1989) required for productive soils in this ecological zone.

The abattoir effluent contaminated soils however, recorded higher values for organic carbon. Yahaya(2009) and Alorge(1992), reported similar values for organic carbon content for soils contaminated with abattoir effluent in Sokoto and Niger. The high organic carbon content of abattoir effluent contaminated soils may be due to decomposition and composting of the animal waste (dung, body part, bones and blood) and plant/vegetable matter from the surrounding environment (Yahaya, 2009).

Total nitrogen contents were low $(<0.2)$ (Landon, 1991) for the control soils with values ranging from 0.08 to $0.09 \%$ and medium in the abattoir effluent contaminated soils with values between 0.18 and $0.65 \%$. The low nitrogen content of the control soils could be attributed to low organic matter content of the soil compounded by severe leaching loses. 
The available phosphorus content of the control soil was medium $\left(<17 \mathrm{mg} \mathrm{kg}^{-1}\right)$. This could be as a result of the strong acidic conditions as indicated by the $\mathrm{pH}$ values. The abattoir effluent contaminated soils were however, observed to be richer in phosphorus content with values $>20 \mathrm{mg} \mathrm{kg}^{-1}$. Excess $\mathrm{P}$ in soil can be worrisome as it could cause plant to mature too rapidly, reduce $\mathrm{Zn}, \mathrm{Cu}$ and $\mathrm{Fe}$ availability and also reduce the uptake of $\mathrm{Mn}, \mathrm{Zn}, \mathrm{Cu}$ and Mo.

The exchangeable bases were generally low $\left(\mathrm{Mg}: 0.6-2.4 \mathrm{cmol} \mathrm{kg}^{-1} ; \mathrm{K}: 0.07-0.09 \mathrm{cmol} \mathrm{kg}^{-1}, 0.05-0.07 \mathrm{cmol} \mathrm{kg}^{-1}\right)$ (Landon 1991, Holland et al., 1989, ) in the control site and higher in abattoir effluent contaminated soils with the following ranges of values: $\mathrm{Ca}\left(12.6-15.6 \mathrm{cmol} \mathrm{kg}^{-1}\right), \mathrm{Mg}\left(2.0-9.8 \mathrm{cmol} \mathrm{kg}^{-1}\right)$, and $\mathrm{K}\left(0.1-0.22 \mathrm{cmol} \mathrm{kg}^{-1}\right)$, and $\mathrm{Na}\left(0.1-0.12 \mathrm{cmol} \mathrm{kg}^{-1}\right)$ than the control. The low Na values indicates that the soils are non-sodic. The abundance of the exchangeable basic cations for the abattoir soil, is in the decreasing order $\mathrm{Ca}, \mathrm{Mg}, \mathrm{K}$ and Na. Exchangeable acidity was generally low (<0.4) (Landon 1991, Holland et al., 1989), in both control and abattoir contaminated soil.

The ECEC values for the control soils were low $\left(<10.5 \mathrm{cmol} \mathrm{kg}^{-1}\right)$ while values obtained for the effluent contaminated site were $>16.30 \mathrm{cmol} \mathrm{kg}^{-1}$. The total exchangeable bases for the control was low in relative to the effective cation exchange capacity (ECEC). Effective cation exchange capacity in the abattoir effluent contaminated soils ranged between $15.91 \mathrm{cmolkg}^{-1}$ and 25.37. These values are moderate (Holland et al., 1989) andare mainly contributed by exchangeable $\mathrm{Ca}^{2+}, \mathrm{Mg}^{2+}$ and acidity parameters. The percentage base saturation of the abattoir effluent contaminated soils had values above $80 \%$ suggestingthe availability of basic nutrient in soil solution.

Comparing data from the three abattoir sites, IkotEneobong had relatively higher enrichment of exchangeable Ca, $\mathrm{Mg}$ and $\mathrm{K}$, than Nasarawa and Atimbo. The enrichment of these exchangeable bases at the abattoir site and relatively low values for exchangeable acidity, indicates the availability of most soil nutrients.

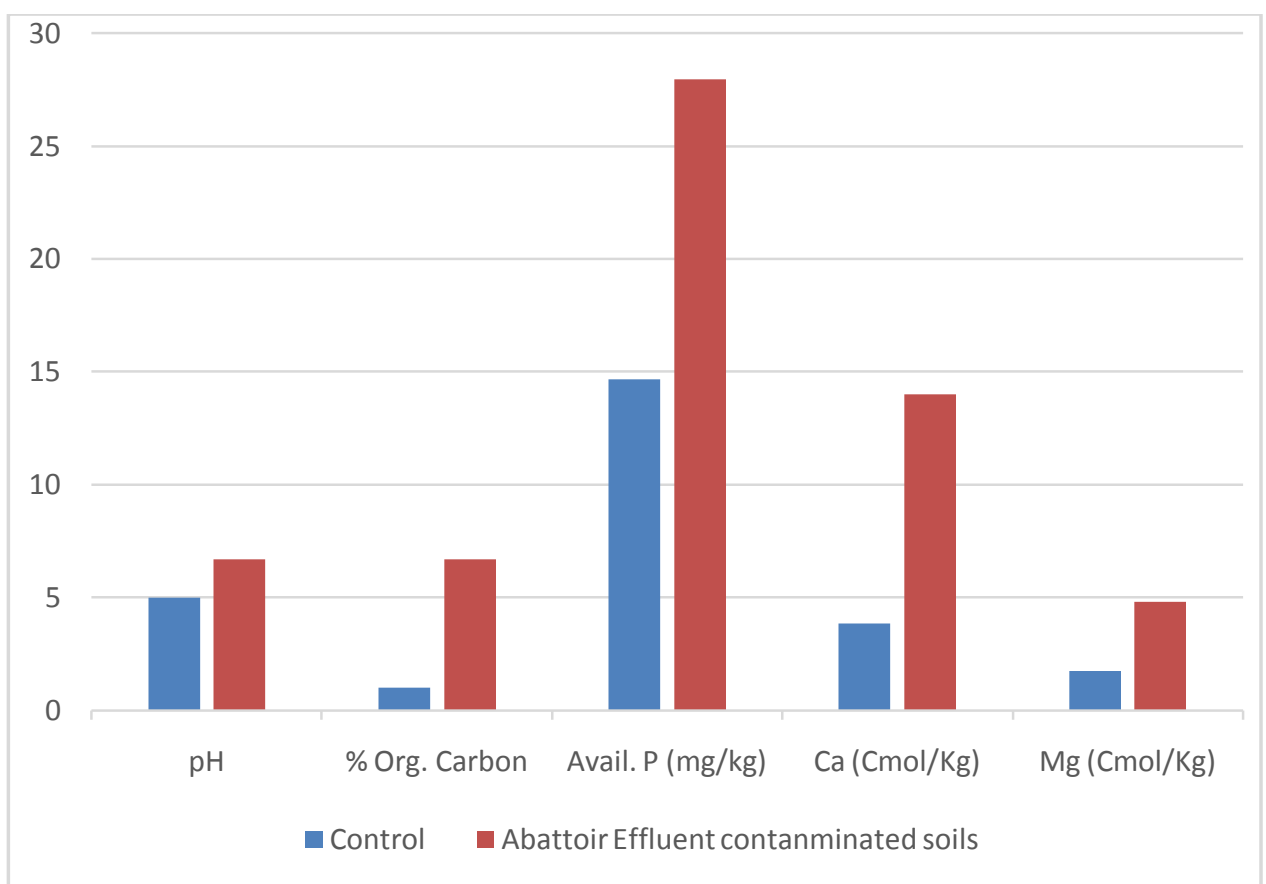

Figure 1:- Mean concentration of chemicals in the control and abattoir effluentcontaminated soils.

\section{Conclusion:-}

This study observed the enrichment of nutrients in the abattoir effluent contaminated soils in Atimbo, IkotEneobong and Nasarawa areas of Calabar. It is recommended that abattoir effluents be properly channeled into septic tanks to avoid luxury consumption by plants in surrounding environments. If properly treated, abattoir effluent could be harnessed for liquid organic fertilizer. 


\section{References:-}

1. Alorge, D.O. (1992). Abattoir design management and effluent disposal in Niger. University of Ibadan Press.

2. Black, C.A., Evans, D.D., White, J.L., Ensminger, L.E. and Clark, F.E. (Eds.). (1965). Methods of soil analysis. Part 2. Agronomy, Madison: Soil Science Society of America.

3. Bray, F.R.H. and Kurtz, L.T. (1945). Determination of total organic and available forms of phosphorus in soils. Soil Science, 59: 39-45.

4. Bouyucos, G.H. (1957). A recalibration of the hydrometer method for making mechanical analysis of soils, Agronomy Journal, 43: 4434 - 4438.

5. Edward, C. (1990). Microbiology of extreme environments. $2^{\text {nd }}$ edition. Open University Press, Milton Keynes.

6. Ezeoha, S. and Ugwuishiwu, B. (2011). Status of abattoir waste research in Nigeria. Nigerian Journal of technology 30 (2) 143-148

7. Federal Department of Agricultural Land Resources (FDALR, 1990). Landon, 1991.

8. Holland, M. D. G; Barton, A. D. and Morph, S.T. (1989). Land Evaluation for Agricultural Recommendation of Cross River National Park. Oban Division. Prepared by Odwki in Collaboration with INNF.

9. Landon, J. R. (1991). Booker tropical soil manual: Hand book on soil survey and agricultural land evaluation in the tropic and sub - tropics. Edinburgh, and Booker Tate limited.

10. Rabah, A.B., Oyeleke, S. B. Manga, S.B. \& Hassan, L.G. and Ijah U.J.J. (2010). Microbiological and physicochemical assessment of soil contaminated with abattoir effluents in Sokoto metropolis, Nigeria. Nigerian Journal of Basic and Applied Sciences, 16(2): 145 - 150.

11. Tortora, G.J., Funke, B R and Case, C.L (2007).Microbiology: An Introduction. (th Edition. Benjamin/Cummings Publishing Company Inc. California.

12. Ubwa, S. T., Atoo, G.H., Offem, J.O., Abah, J and Asemave, K (2013). Effect of activities at Gboko abattoir on some physical properties and heavy metals levels of surrounding soil. International Journal of chemistry 5(3): 14.

13. Walkley, A. and Black, I.B. (1934). An examination of the degtjareff method at determining soil organic matter a modification of the chromic acid titration methods. Soil Science, 37: $29-38$.

14. Yahaya, M.I., Mohammed, S. and Abdujahi, B.K. (2009). Seasonal variation of heavy metals concentration in abattoir dumping site soil in Nigeria. J. Appl. Sci. Environ. Manag. 13(4): $9-13$. 